\title{
ARTICLES
}

Submitted 09.24.2019. Approved 06.02.04.2020

Evaluated through a double-blind review process. Scientific Editor: Henrique Correa

Original version

DOI: http://dx.doi.org/10.1590/So034-759020210204

\section{HIGH-PERFORMANCE LEVEL AND TECHNOLOGY MANAGEMENT AMONG WINERY FIRMS IN THE WINE INDUSTRY CLUSTER OF BAJA CALIFORNIA: A FSQCA APPROACH}

\author{
Nivel de alto desempenho e gerenciamento de tecnologia entre empresas \\ vinícolas no cluster da indústria do vinho da Baixa Califórnia: Abordagem FSQCA \\ Alto nivel de desempeño y gestión tecnológica en las empresas vitivinícolas del \\ clúster vinícola de Baja California: Un enfoque fs $Q C A$
}

\begin{abstract}
This paper analyzes how wineries in the wine industry cluster of Baja California in Mexico achieve a high-performance level and engage in technology management. The study uses the fuzzy-set qualitative comparative analysis approach to inquire into the necessary and sufficient conditions for firms in this industry cluster to attain a high-performance level. Our research hypothesis suggests that the presence of some resources (conditions) in the wine industry cluster of Baja California is a necessary and sufficient condition (set-theoretic relations) to achieve a high-performance level (outcome). Accordingly, this study examines the causal complexity observed in set-theoretic relations and high-performance levels in the wine industry cluster of Baja California. An important finding in this research is that winery firms in Baja California do not need to develop interdependent innovations to achieve a high-performance level. However, research and development efforts, good supplier relations, and production capacity are necessary conditions to achieve a high performance level in this cluster.
\end{abstract}

KEYWORDS | High performance level, technology management, wine industry, fuzzy-set qualitative comparative analysis, Baja California.

\section{RESUMO}

Este artigo analisa o nível de alto desempenho e o gerenciamento de tecnologia entre as empresas de vinificação do cluster da indústria vinícola da Baixa Califórnia, no México. O estudo usa a abordagem de análise comparativa qualitativa de conjunto difuso ( $f$ SQCA) para investigar as condições necessárias e suficientes para atingir um nível de alto desempenho entre as empresas desse cluster da indústria. A hipótese sugere que a presença de alguns recursos (condições) no cluster da indústria vinícola da Baixa Califórnia é condição necessária e suficiente (relações teóricas) para alcançar um nível de alto desempenho (resultado). Nesse sentido, este estudo examina a complexidade causal observada nas relações teóricas dos conjuntos e no nível de alto desempenho no cluster da indústria vinícola da Baixa Califórnia. Uma descoberta importante nesta pesquisa é que as empresas de vinhedos da Baixa Califórnia não precisam desenvolver inovações interdependentes para alcançar um nível de alto desempenho. No entanto, esforços de pesquisa e desenvolvimento, boas relações com fornecedores e capacidade de produção são condições necessárias para atingir um nível de alto desempenho.

JOSÉ CARLOS RODRÍGUEZ ${ }^{1}$

jcrodriguez@umich.mx

0000-0002-0942-8017

\section{MARIO GÓMEZ ${ }^{1}$}

mgomez@umich.mx

0000-0002-4906-0966

\section{MARÍA ALINE MANZO' ${ }^{1}$}

mmanzo@umich.mx

oooo-0003-4379-179X

1 Universidad Michoacana de San Nicolás de Hidalgo, Instituto de Investigaciones Económicas y Empresariales, Michoacán, México
PALAVRAS-CHAVE I Nivel de alto desempenho, gerenciamento de tecnologia, indústria de vinhos, análise comparativa qualitativa de conjunto difuso, Baixa Califórnia.

\section{RESUMEN}

Este artículo analiza el alto nivel rendimiento y la gestión tecnológica en las empresas vitivinícolas del clúster industrial vinícola de Baja California en México. El estudio utiliza el análisis cualitativo comparado (fsQCA, por sus siglas en inglés) para determinar las condiciones necesarias y suficientes para alcanzar un alto desempeño entre las empresas de este clúster industrial. La hipótesis en esta investigación sugiere que la presencia de ciertos recursos (condiciones) en el clúster industrial vitivinícola de Baja California son condiciones necesarias y suficientes (relaciones de conjuntos teóricas) para alcanzar un alto nivel de rendimiento (resultado). Este trabajo analiza la complejidad causal que existe en relaciones de conjuntos teóricas y un alto nivel de desempeño en el clúster industrial vitivinícola de Baja California. Un hallazgo importante en esta investigación es que las empresas vitivinícolas de Baja California no necesitan desarrollar innovaciones conjuntas para alcanzar un alto nivel de desempeño. De igual forma, los esfuerzos para la investigación y desarrollo, las relaciones con proveedores y la capacidad de producción son condiciones necesarias para alcanzar un alto nivel de desempeño en este clúster.

PALABRAS CLAVE I Nivel de alto desempeño, gestión tecnológica, industrial vitivinícola, análisis cualitativo comparado y conjuntos difusos, Baja California. 


\section{INTRODUCTION}

In their 2012 paper entitled "Is Baja California, Mexico, wine industry a cluster?” Trejo-Pech, Arellano-Sada, Coelho, and Weldon (2012) ask whether the winery region of Baja California in Mexico can be considered a wine industry cluster. These authors concluded that Baja California must be considered a successful industry cluster (Trejo-Pech et al., 2012). Accordingly, the theoretical perspective adopted in this research is the industry cluster approach (Porter, 1998a, 1998b).

The wine industry in Mexico is made up of more than 216 wineries and 70 commercializing companies (GóngoraRosado, 2016). Wine grapes are grown on 6,474 hectares of vineyards in 11 Mexican states (El Universal, 2018a; González-Andrade, 2015). However, Baja California is the most important producer of grapevines, accounting for around $60 \%(3,735$ hectares $)$ of the total vineyards cultivated in Mexico (González-Andrade, 2015). A Mediterranean climate makes Baja California the region best suited to produce highquality grapes, supplying more than $85 \%$ of total Mexican wine through 350 wine labels and 2 million cases equivalent to a value of 378 million Mexican pesos (Consejo Mexicano Vitivinícola [CMV], 2018; González-Andrade, 2015; Secretaria de Fomento Agropecuario [SEFOA], 2011). Ensenada, Tecate, and Tijuana are the most important wine-producing locations in Baja California, where numerous wineries and other supporting firms make up the region's wine industry cluster (González-Andrade, 2015; Trejo-Pech et al., 2012).

The objective of this research is thus to reveal the necessary and sufficient conditions (set-theoretic relations) to achieve a high-performance level (outcome) among winery firms in the wine industry cluster of Baja California. The research method adopted in this study is the fuzzyset qualitative comparative analysis ( $\mathrm{fSQCA}$ ) that allows integrating into the same analysis qualitative and quantitative methods (set-theoretic relations) that generate a specific outcome (Berger, 2016; Parente \& Federo, 2019; Ragin, 2008; Rihoux \& Ragin, 2009). The fsQCA approach also contributes to revealing the complex causality between conditions in a small number of cases through determining the necessary and sufficient conditions (set-theoretic relations) that generate a specific outcome (Ragin, 2000, 2008). The research hypothesis is specified in a configurational manner by developing substitution and complementarity logics among conditions that produce the outcome of interest (Parente \& Federo, 2019). Therefore, the research question examined in this study is as follows: which are the necessary and sufficient conditions (set-theoretic relations) among winery firms in the wine industry cluster of Baja California that allow a highperformance level (outcome) to be achieved? In this sense, fs QCA methods offer insight into how firms may develop a competitive market advantage (Porter, 1997, 1998a; Porter \& Stern, 2001).

\section{LITERATURE REVIEW}

\section{The wine industry in Mexico}

Winemaking has a long history in Mexico. It is considered the oldest wine-growing region in North America, dating back to 1522 when grapevines were introduced from Spain (Bringas \& González, 2004; Covarrubias \& Thach, 2015; Meraz-Ruiz, 2015). Nevertheless, the earliest Mexican wines were crafted in 1707 , but it was only a few years ago that Mexico started producing, advertising, and marketing wine (Covarrubias \& Thach, 2015; Wines of Baja, 2013). Nowadays, several civil associations in Mexico are related to wine production and allied with the International Wine Organization (IWO) to support the production and promotion of high-quality wine (GonzálezAndrade, 2015).

The viticulture in Baja California is an example of how Mexican wineries have developed a high-quality and competitive industry with international recognition (Góngora-Rosado, 2016; Meraz-Ruiz, 2015). However, the viticulture in Mexico continues to be mostly a regional and small-scale industry, with Mexico ranking as the $25^{\text {th }}$-largest wine producer in the world (GarcíaFernández, Meraz-Ruiz, \& Díaz-Gómez, 2018; Góngora-Rosado, 2016; González-Andrade, 2015). It is Mexico's climate that makes it possible to produce high-quality wine and positions Mexico as an outstanding wine producer and competitor in international markets (Góngora-Rosado, 2016; Meraz-Ruiz, 2015). Examples of successful wine producers in Baja California are L.A. Cetto, Casa Domeca, Bodegas de Santo Tomás, and Monte Xanic (Covarrubias \& Thach, 2015). Indeed, the five-largest wineries from this region account for more than $15 \%$ of Mexican wine production (Covarrubias \& Thach, 2015). Mexican wineries exported 500,000 cases of wine in 2018 , notably to Belize ( $2 \%)$, Canada (4\%), Denmark (1\%), France (1\%), Japan (30\%), the United States (51\%), and the United Kingdom (2\%) (Milenio, 2018). Japan and the United States are the most important markets for Mexican wine. Figure 1 shows Mexico's wine exports by country of destination. 
Figure 1. Mexico's wine exports by country of destination

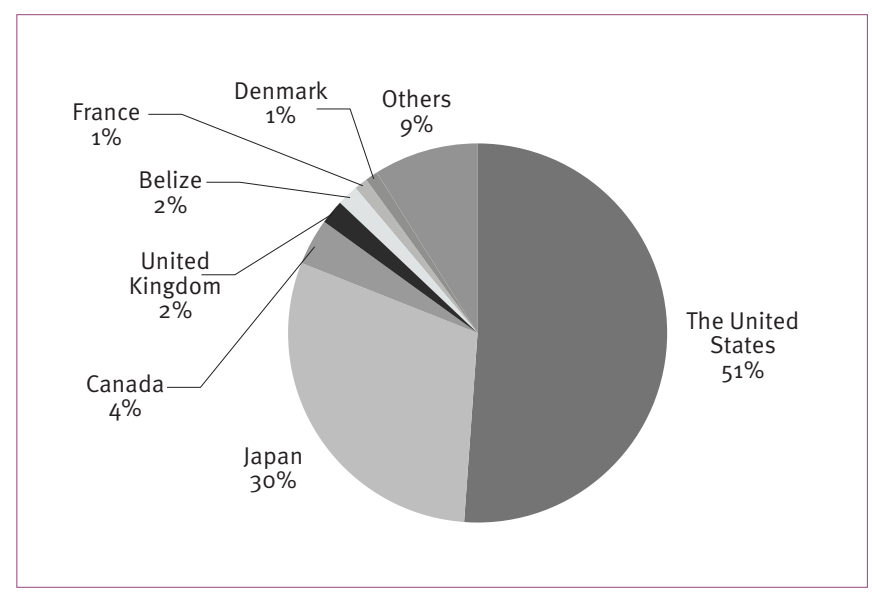

Source: Milenio (2018).

The Consejo Mexicano Vitivinícola (Mexican Board of Wine, CMV) has emphasized the importance of the Mexican wine industry in recent years with a growth equivalent to $8 \%$ of the total world wine production in 2017 and a remarkable increase in demand in national and international markets (El Conocedor, 2016; García-Fernández et al., 2018)

Grapevine farming is practiced in 11 Mexican states, namely, Aguascalientes, Baja California, Chihuahua, Coahuila, Guanajuato, Nuevo León, Puebla, Querétaro, San Luis Potosí, Sonora, and Zacatecas (Figure 2) (El Universal, 2018a; MerazRuiz \& Ruiz Vega, 2016) over a total of 6,474 hectares of vineyards. Nevertheless, $97 \%$ out of total grapevine production is concentrated in Aguascalientes, Baja California, Coahuila, Guanajuato, Querétaro, and Zacatecas (Meraz-Ruiz \& Ruiz Vega, 2016). Indeed, Baja California accounts for almost $60 \%$ of the total vineyards cultivated in Mexico, equivalent to 3,735 hectares (González-Andrade, 2015; Trejo-Pech et al., 2012). Furthermore, Mexican wineries offer 350 wine labels and 2 million cases, equivalent to 2.5 million liters of wine a year (El Universal, 2018a). In 2017, Mexican wine production value was equivalent to 378 million Mexican pesos, while its commercialization value was equivalent to 1,588 million Mexican pesos, and thus the Mexican wine chain value was equivalent to 1,966 million Mexican pesos during the same year (El Universal, 2018a).

However, the main challenge to be addressed by Mexican producers is threefold (Meraz-Ruiz \& Ruiz-Vega, 2016): environmental restrictions (e.g., insufficient water in vineyards), the opportunity to get adequate inputs from abroad, and a high concentration in the glass industry. Even if these are enormous tasks, Mexican wine producers are currently offering high-quality labels in national and international markets (García-Fernández et al., 2018). Nevertheless, winery owners have proposed that the Mexican government support the wine industry through an adequate policy that includes tax discounts, sponsoring, and subsidizing wine production, as well as establishing a regulatory framework to promote, develop, and diffuse wine production through supporting innovation activities (Diario Oficial de la Federación [DOF], 2018; González-Andrade, 2015). Consequently, the Mexican government passed the 2018 Ley de Fomento a la Industria Vitivinícola (Act for the Promotion of the Wine Industry) intended to support the competitiveness of Mexican wineries. This initiative projected that wine production would rise by $50 \%$ through an increase of 15,000 hectares of cultivated vineyards in ten years (DOF, 2018; Industrial News Baja California [INBC], 2018). Furthermore, the $\mathrm{CMV}$ works to standardize the quality of Mexican wine made $100 \%$ with Mexican grapes. Finally, winemaking in Mexico profits from soil minerality and salinity; grapevine sweetness; and, crucially, environmental and legal conditions that contribute to the competitiveness of this industry (GarcíaFernández et al., 2018; González-Andrade, 2015).

\section{Figure 2. Grapevine producers in Mexico by state}

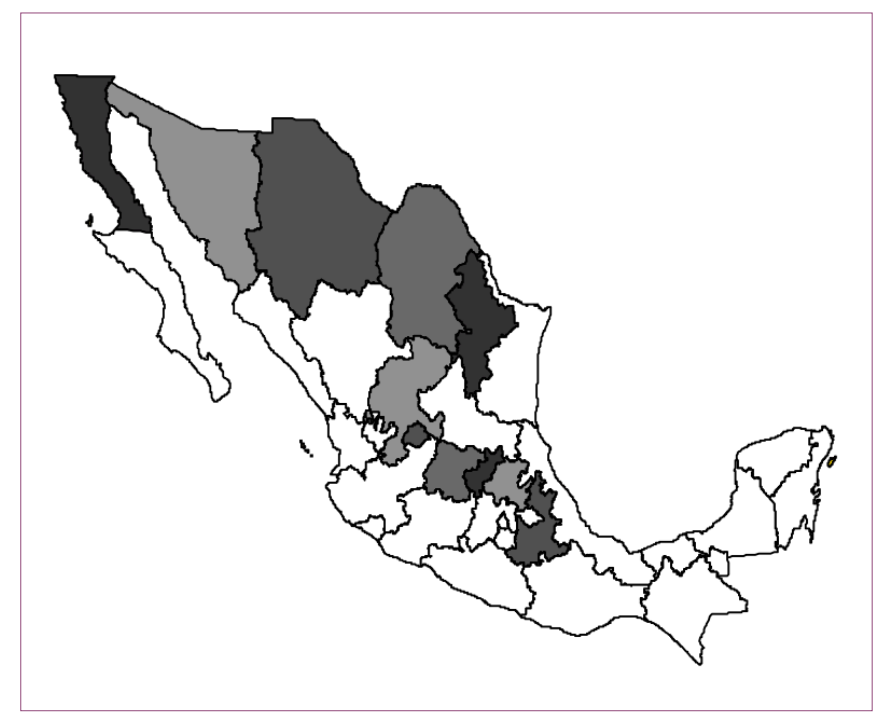

Source: El Universal (2018a).

\section{Theoretical approaches on innovation policy}

There are at least four theoretical approaches in the literature on how innovation activity is carried out (Rinkinen \& Harmaakorpi, 2018):

- The innovation systems perspective,

- The smart specialization (SmSp) approach, 
- The business ecosystem viewpoint,

- The industry cluster approach.

However, each approach responds to specific questions in the analysis of innovation (Rinkinen \& Harmaakorpi, 2018). For example, the innovation systems perspective studies innovation as a systemic phenomenon at different levels of analysis: (i) national (Freeman, 1987; Lundvall, 1992; Nelson, 1993), (ii) regional (Cooke, 1992, 1998), and (iii) sectoral/technological (Malerba, 2002). The innovation systems perspective offers insight into how innovation activity is carried out when applying alternative innovation policies (Edquist, 1997). From this perspective, the linkages between information and knowledge flows, investment funding, flows of authority, and networks of partnerships must be included in the analysis (Cooke, 1998). However, market failures and other system imperfections must be at the core of innovation systems analysis because of the need to define suitable innovation policies (Asheim, Smith, \& Oughton, 2011; Cooke, 1998; Harmaakorpi, 2006; Jauhiainen, 2009; Smits \& Kuhlmann, 2004).

The SmSp concept was primarily developed as an alternative innovation policy approach, stressing the differences between regions when such policies were implemented (e.g., Europe and the United States) (Camagni \& Capello, 2013; Foray \& Ark, 2007; McCann \& Ortega-Argilés, 2013). This perspective is about a targeted use of funding and investment in fields with the most promising innovation potential (e.g., new combinations of resources, and new niches and cross-cutting fields of expertise) (Rinkinen \& Harmaakorpi, 2018). SmSp is based on the principles of embeddedness, relatedness, and connectedness (Foray et al., 2012). However, there is no universal innovation policy in the $\mathrm{SmSp}$ approach but several independent innovation policies in order for each region to create its appropriate strategy, goals, and action plan (Rinkinen \& Harmaakorpi, 2018).

The business ecosystems perspective suggests that innovative firms must be considered as part of an ecosystem (Moore, 1993, 2006). An essential feature in this approach is that firms simultaneously cooperate and compete to co-evolve when developing innovations (Moore, 1993). Indeed, firms contribute to the business ecosystem value network in which value is co-created by all of them (Leviäkangas et al., 2014; Peppard \& Rylander 2006). Business ecosystems are defined as "a type of a business network, a collaboration to create a system of complementary capabilities and companies" (Moore, 2006). Indeed, there are four stages when developing business ecosystems (Moore, 2006): birth, expansion, leadership, and self-renewal or death. The innovation policy that follows from this perspective is intended to support cooperation activities among firms within an ecosystem.

Finally, the industry cluster approach demonstrates how firms within a geographic agglomeration may support innovation activity to develop a competitive advantage (Porter, 1998a, 1998b, $2000 a, 2000$ b). It considers the importance of several actors in the process of developing innovation activities. The innovation policy drawn from the industry cluster approach suggests that firms within a cluster must compete and cooperate at the same time. This theoretical approach will be discussed in more detail in the next section.

\section{The industry cluster approach}

The industry cluster approach has evolved into a comprehensive stream of literature. This trend arises because of the importance given to clusters and local specialization in academic and political analyses during the last few decades (Cruz \& Teixeira, 2010). Industry clusters are defined as "geographic concentrations of interconnected companies and institutions in a particular field" (Porter, 1998a, p. 78). This approach analyzes competitiveness and innovation activity among a geographic agglomeration of firms (Martin \& Sunley, 2003; Porter, 1998a, 1998b, 2000a, 200ob). It includes many actors and institutions, such as specialized inputs, providers of specialized infrastructure, companies manufacturing complementary products, government agencies, universities, vocational and specialized training providers, and so forth (Porter, 1998a). Indeed, the interface between these interconnected companies and institutions is commonly a source of competitive advantage (Porter, 1998a).

The cluster approach suggests that competitive advantage is found where business units are based and different actors and innovation activities are located (Porter, 2000a, 2000b; Roelandt \& Hertog, 1999). Therefore, clusters are formed to benefit from knowledge spillovers, trust, and better coordination for innovation (Maskell, 2001; Porter, 1998a). Indeed, cooperation and competition within a cluster is the driving force determining its dynamics (Bell, 2005; Padmore \& Gibson, 1998; Porter, 1998a). Competition increases productivity and innovation through stimulating the formation of new firms, while cooperation establishes the basis of the cluster development (Porter, 1998a). In this regard, firms within a cluster cooperate with other firms typically through hierarchies, and the development of company relationships contributes to diminishing competition when it is necessary to determine long-run profits (Leavy, 1996; Porter, 1998a). Competition and cooperation can coexist because they 
occur on different dimensions between different players (Porter, 1998a).

Finally, the innovation policy drawn from the industry cluster approach stresses the importance of improving productivity and regional economic growth (Porter, 1998b). It seeks to guarantee the possibility of better conditions to access employees, suppliers, specialized information, institutions and public goods, perceptions of emerging buyer needs, innovation opportunities, and so forth (Porter, 1998b, 2000a). Importantly, the concept of industry cluster has not been exempted from some criticisms concerning its definition, theorization, empirical inquiry, and use in policy making (Martin \& Sunley, 2003)

\section{THE WINE INDUSTRY CLUSTER OF BAJA CALIFORNIA}

A well-known example of a wine industry cluster is California (Porter, 1998a). This example shows how commercial wineries, independent wine grape growers, suppliers of grape stock, irrigation, harvesting equipment and barrel suppliers, and specialized public relations and advertising firms are interconnected through a network of complex linkages (Porter, 1998a). However, there are many other examples in the literature on wine industry clusters in the world (Trejo-Pech et al., 2012): Baja California (Mexico), Barossa Valley (Australia), Champagne and Bordeaux (France), Colchagua Valley (Chile), Mendoza (Argentina), Napa Valley (United States), and Rioja (Spain).

The wine industry cluster of Baja California possesses some specific features that make it rather different from other clusters, mainly soil minerality and salinity, grapevine sweetness, and environmental and legal conditions. These features have allowed Baja California to gain an international reputation for the quality of its wine (González-Andrade, 2015; López, House, \& Trejo-Pech, 2010; Trejo-Pech et al., 2012). Indeed, the climate in Baja California particularly favors high-quality crops, ensuring a successful industry cluster (SEFOA, 2011). It is noteworthy that Ensenada, Tijuana, and Tecate are the most important areas in the Baja California region, producing around $90 \%$ of Mexican wine from 150 winery firms of varying sizes, and using different techniques (e.g., modern, handmade, and craft techniques) (Alpízar-Padilla \& Maldonado-Ávalos, 2009; Quiñonez-Ramírez, Bringas-Rábago, \& Barrios-Prieto, 2011; Góngora-Rosado, 2016; SEFOA, 2011). Table 1 shows the main grape varieties cultivated in Baja California (CMV, 2015; MerazRuiz, 2015).
Table 1. Grape varieties cultivated in Baja California

\begin{tabular}{l|c|c}
\hline GRAPE VARIETY & HECTARES & $\%$ \\
\hline Cabernet sauvignon & 592.8 & 21.4 \\
\hline Chenin blanc & 216.7 & 7.8 \\
\hline Merlot & 205.3 & 7.4 \\
\hline Grenache & 158.8 & 5.7 \\
\hline Nebbiolo & 156.2 & 5.6 \\
\hline Chardonnay & 145.9 & 5.3 \\
\hline Zinfandel & 140.0 & 5.0 \\
\hline Tempranillo & 126.1 & 4.5 \\
\hline Sauvignon blanc & 121.8 & 4.4 \\
\hline Syrah & 112.8 & 4.1 \\
\hline Petite syrah & 689.3 & 4.0 \\
\hline Other & 110.4 & 4.8 \\
\hline Sce:civ & & 4.4 \\
\hline
\end{tabular}

Source: CMV (2015), Meraz-Ruiz (2015).

Finally, the wine industry cluster of Baja California has developed as highly competitive, characterized by some features (OIV, 2010; Trejo-Pech et al., 2012):

- Grapes are cultivated in a Mediterranean climate (e.g., Valle de Guadalupe).

- There is a strong collaboration between winery firms and other actors that generate collective knowledge.

- There is a deep interaction between identifiable physical and biological environments.

- Some successful vitivinicultural practices have been implemented.

Indeed, these characteristics refer to the existence of a highly competitive vitivinicultural terroir in this region, leading Baja California winery firms to develop a competitive advantage (OIV, 2010; Porter, 1997, 2008; Porter \& Stern, 2001; Rodríguez, Gómez, \& Ramírez, 2015). 


\section{EMPIRICAL ANALYSIS}

\section{fsQCA methods}

During recent years, scholars in the social sciences have been increasingly interested in QCA applications and methods (Schneider \& Wagemann, 2010). Thus, QCA methods have been modified, extended, and improved to answer scientific questions, contributing to achieving further progress in the social sciences (Berger, 2016; Huarng \& Roig-Tierno, 2016; Ragin, 2000, 2006, 2008; Ragin \& Sonnett, 2004). The QCA methodology is a comparative case-oriented approach that allows the minimally necessary and/or minimal conditions to bring about an outcome to be identified (Vis, 2012). It is an approach based on set-theoretic relations and Boolean algebra that combines qualitative and quantitative methods to gain insight into the interactions of set memberships (Marx, Rihoux, \& Ragin, 2014; Parente \& Federo, 2019; Ragin, 2000, 2008; RoigTierno, González-Cruz, \& Llopis-Martínez, 2017). In this way, the comparative case-oriented approach of QCA is capable of establishing set-theoretic relations that enable theorizing and examining the causal complexity of social phenomena characterized by nonlinearities and asymmetries (Parente \& Federo, 2019; Rihoux \& Ragin, 2009).

The theoretical explanations in QCA are not about the net effect of individual variables on an outcome (e.g., econometric analysis) but the causal conditions on a desired state or outcome (Radaelli \& Wagemann, 2019). Therefore, causality in QCA is understood as a complex, conjunctural, equifinal, and asymmetric method based on set-theoretic relationships that make use of the principles of necessary and sufficient conditions (Parente \& Federo, 2019). This possibility allows us to unravel the causal complexity characterizing social phenomena through analyzing multiple independent causal attributes associated with a given outcome (conjunction), exploring different combinations of conditions associated with an outcome (equifinality), and assessing the possibility that the presence and the absence of attributes could be associated to an outcome (asymmetry) (Parente \& Federo, 2019). The basis of QCA is thus the study of the configurations that consistently produce sufficient and necessary conditions to generate a desired state or outcome (Parente \& Federo, 2019; Ragin, 2000, 2006, 2008; Roig-Tierno et al., 2017). Nowadays, QCA methods have been used in several disciplines, such as public policy and political science, business and management, or even industrial engineering and computer sciences (Huarng \& Roig-Tierno, 2016; Marx et al., 2014; Mendel \& Korjani, 2012, 2013; Roig-Tierno, Huarng, \& Ribeiro-Soriano, 2016).
There are three main approaches in QCA: crisp-set QCA (csQCA), fuzzy-set QCA (fsQCA), and multi-value QCA (mvQVA) (Ragin, 2000, 2006, 2008; Roig-Tierno et al., 2017). Certainly, QCA applications have evolved from using solely crisp sets into incorporating fuzzy sets with more finely grained degrees of membership (Parente \& Federo, 2019). In particular, the fsQCA approach gives qualitative comparative analysis the possibility of managing several levels of membership when constructing logical propositions (Ragin, 2000; Roig-Tierno et al., 2017). Hence, the research questions typically raised in QCA concern the necessary and/or sufficient conditions to achieve an outcome (Cotte \& Pardo, 2013; Vis, 2012). The aim is, therefore, to find out the logical connections between combinations of causal conditions that bring about a desired state or outcome (Roig-Tierno et al., 2017).

In the case of $\mathrm{fs} Q \mathrm{CA}$ research, the inquiry procedure allows the transformation of qualitative information into quantitative values to discover the missing associations between independent and dependent conditions, as well as provide a systematic approach for data calibration and quantification of qualitative fuzzy-set data (Fiss, 2007; Ragin, 2000, 2008; Roig-Tierno et al., 2017; Schneider \& Wagemann, 2010, 2012). Thus, the fsQCA approach reveals how to deal with complexity among conditions, typically in a small number of cases (Ragin, 2000, 2006, 2008). Importantly, even if QCA was initially developed to find consistent relationships among small samples, it is also applied now to samples ranging from small to large (Parente \& Federo, 2019).

The application of fsQCA methods proceeds in four steps (Marx et al., 2014; Ragin, 2006, 2008): (i) configurational model design and calibration, (ii) development of raw and modified truth tables, (iii) consistency analysis, and (iv) solution analysis. The configurational model design and calibration process implies transforming the explanatory conditions and outcome into settheoretic relations to build the raw and truth modified tables of alternative configurations. This process allows the establishment of the consistency cutoff to distinguish causal combinations that are or are not part of the outcome that generates similar solutions (Ragin, 2006, 2008). The solutions occur along the complexity and parsimoniousness continuum in which the intermediate solution is often the most interpretable (Ragin, 2006, 2008).

It is essential to consider two additional concepts when applying fsQCA methods (Roig-Tierno et al., 2017): consistency and coverage. "Consistency" refers to the percentage of causal configurations with an identical outcome, while "coverage" (explanatory power or empirical relevance) refers to the number of cases with a valid configuration (Marx et al., 2014; RoigTierno et al., 2017). Accordingly, this research aims to identify the necessary and sufficient conditions leading winery firms to 
achieve a high-performance level in the wine industry cluster of Baja California. Furthermore, this analysis will reveal the complexity (causal ambiguity) of the interconnections between companies and institutions within the wine industry cluster of Baja California when implementing a particular strategy to achieve a high-performance level.

\section{Hypothesis and explanatory conditions}

The wine industry cluster of Baja California is an example of a successful strategy to position Mexican wine in both domestic and international markets. Table 2 shows the internal and external conditions of the wine industry cluster of Baja California that explain this strategy. The internal conditions are R\&D efforts (R\&D), specialized human capital (SHC), product and process innovation (PPI), and production capacity (PC), while the external conditions are good supplier relations (GSR), consumer satisfaction (CS), good complementary relationships (GCR), and interdependent innovation (IINN). Consequently, the hypothesis in this research is as follows:

$\mathrm{H}_{1}$ : The presence of GSR, CS, GCR, and IINN, on the one hand, and of R\&D, SHC, PPI, and PC, on the other, are necessary and sufficient conditions (set-theoretic relation) to achieve a high-performance level (HPL) (outcome) among firms in the wine industry cluster of Baja California.

\section{Table 2. Outcomes and internal and external conditions}

\begin{tabular}{|c|c|}
\hline OUTCOME & DESCRIPTION \\
\hline High performance level (HPL) & Profits \\
\hline \multicolumn{2}{|c|}{ INTERNAL CONDITIONS (SELECTED FIRMS ACTIVITIES) } \\
\hline R\&D efforts (R\&D) & Firm investment in R\&D activities \\
\hline Product and process innovation (PPI) & Plant and field technology \\
\hline Production capacity (PC) & Annual current production \\
\hline Consumer satisfaction (CS) & Awards obtained and number of labels \\
\hline Good complementary relationships (GCR) & Agreements and contracts with local producers \\
\hline Interdependent innovations (IINN) & Government financing and active participation in professional associations \\
\hline
\end{tabular}

This hypothesis is shortened in Combination 1 through Boolean algebra as a necessary and sufficient condition to achieve a high-performance level among firms in the wine industry cluster of Baja California:

$G S R$ * $C S$ * GCR * IINN * R\&D * SHC * PPI * PC .... * HPL (1)

\section{Cases and data collection}

Empirical data were collected from interviews at six wineries established in Baja California, during 2018. Respondents were asked about firm performance and other activities constituting the configuration conditions that lead to a high-performance level. The sample selection corresponded to the wineries' position in terms of sales and production. Other information on the characteristics featuring this cluster was collected from CMV sources (CMV, 2015, 2018). Therefore, data from wineries included firm size, hectares of cultivated vineyards, annual case production, variety of vines, labels, and product awards. Suitable cases needed to explain the high-performance level among winery firms in this industry cluster were included in the sample (Parente \& Federo, 2019). Table 3 shows the wineries analyzed in this research. 
Table 3. Selected wineries in the cluster of Baja California

\begin{tabular}{l|c|c|c|c|c}
\hline WINERY NAME & FOUNDING YEAR & $\begin{array}{c}\text { CULTIVATED } \\
\text { VINEYARDS (HECTARE) }\end{array}$ & $\begin{array}{c}\text { ANNUAL CASES } \\
\text { PRODUCTION }\end{array}$ & VINES VARIETY & $\begin{array}{c}\text { PRODUCT } \\
\text { AWARDS }\end{array}$ \\
\hline Bodegas Santo Tomás & 1888 & 400 & 600,000 & 21 & 10 \\
\hline Casa Pedro Domecq & 1972 & 300 & 100,000 & 21 & 57 \\
\hline $\begin{array}{l}\text { L.A. Cetto de } \\
\text { Guadalupe }\end{array}$ & 1974 & 1,100 & 100 & 40 \\
\hline Monte Xanic & 1988 & 192 & $60,000,000$ & 8 & 20 \\
\hline Vinisterra & 2002 & 20 & 7,000 & 2 & 7 \\
\hline Viña de Liceaga & 1993 & 8 & 5,000 & 4 & 5 \\
\hline
\end{tabular}

Source: From companies' interviews.

Even if the success of Mexican wineries has been outstanding during the last few years, their production capacity is still in the development stage. Indeed, some wineries have applied unconventional business strategies to maintain their market competitiveness. Vinisterra and Viña de Liceaga, for example, have implemented "Ruta del Vino," a highway and paved road system that leads tourists to vineyards and wineries in the wine region of Baja California during the harvest season (Quiñónez-Ramírez et al., 2011).

\section{RESULTS}

The next step in the fsQCA investigation is to calibrate the causal and outcome conditions. In the case of the wine industry cluster of Baja California, the causal conditions correspond to the internal and external explanatory conditions previously discussed in this paper. The outcome condition corresponds to the HPL in this industry cluster. The calibration process was made through the direct method, and thus the explanatory conditions R\&D, SHC, PPI, GSR, CS, GCR, and IINN were fixed as full membership (6 points), crossover point (3 points), and full non-membership (o points) (Ragin, 2006, 2008). Table 4 shows the anchor point for these conditions. In the case of PC, the values were calibrated based on annual case production (Table 4). On the other hand, the calibration values of the HPL were computed based on firm profits, mainly full membership (30 points), cross-over point (9 points), and full non-membership (1 point) that correspond to the media of profits in the Mexican wine industry.

Table 4. Calibration values

\begin{tabular}{l|c|c|c|c}
\hline CONDITION & RANGE & FULL NON-MEMBERSHIP & CROSS-OVER POINT & FULL MEMBERSHIP \\
\hline R\&D & $0-6$ & 0 & 3 & 6 \\
\hline SHC & $0-6$ & 0 & 3 & 6 \\
\hline PPI & $0-6$ & 0 & 3 & 6 \\
\hline GSR & $0-6$ & 0 & 3 & 6 \\
\hline CS & $0-6$ & 0 & 3 & 6 \\
\hline GCR & $0-6$ & 0 & 3 & 6 \\
\hline IINN & $0-6$ & 0 & 99 & 1000 \\
\hline PC & $0-1000$ & 0 & 3 & 6 \\
\hline
\end{tabular}

Table 5 shows the raw truth table of this research. The raw truth table contributes to understanding the results computed in this model. It reveals the configurations of the winery activities in this cluster. Consequently, the gaps in the consistency values are useful for establishing a consistency threshold, and the values below 0.80 show substantial inconsistencies (Ragin, 2008). In this case, the consistency threshold was set at 0.80 for a high-performance level in the truth table. 
Table 5. Raw truth table

\begin{tabular}{c|c|c|c|c|c|c|c|c|c|c|c|c}
\hline RDE & SHC & PPI & GSR & CS & GCR & IINN & PC & NUMBER & HPL & RAW CONS. & PRI CONS. & SYM CONS. \\
\hline 1 & 1 & 1 & 1 & 1 & 1 & 0 & 1 & 4 & 1 & 0.99262 & 0.98823 & 1 \\
\hline 0 & 0 & 1 & 0 & 0 & 0 & 1 & 0 & 1 & 0 & 0.37984 & 0 \\
\hline 0 & 1 & 1 & 0 & 1 & 1 & 1 & 0 & 1 & 0 & 0.37984 & 0 & 0 \\
\hline
\end{tabular}

In the same way, Table 5 shows the configurations that lead to the three solutions: complex (zero logical remainders), intermediate (logical remainders making sense in the final solution), and parsimonious solutions (all logical remainders without any possibility of evaluation) (Ragin, 2000, 2006, 2008). However, in the wine industry cluster of Baja California, the intermediate solution is superior to the other two solutions according to the interpretation of the results (Ragin, 2006, 2008). In this sense, the analysis of the parsimonious and intermediate solutions contributes to determining the central and peripheral causal conditions that shape this research on the explanation of the HPL (Fiss, 2011).

\section{Table 6. Modified truth table}

\begin{tabular}{c|c|c|c|c|c|c|c|c|c|c|c|c}
\hline Conf. & RDE & SHC & PPI & GSR & CS & GCR & IINN & PC & N & Ny & Cons. & X $\ldots$. Y \\
\hline 1 & 1 & 1 & 1 & 1 & 1 & 1 & 0 & 1 & 4 & 4 & 1 & V \\
\hline 2 & 0 & 0 & 1 & 0 & 0 & 0 & 1 & 0 & 1 & 0 & - & F \\
\hline 3 & 0 & 1 & 1 & 0 & 1 & 1 & 1 & 0 & 1 & 0 & - & F \\
\hline
\end{tabular}

Table 6 shows the modified truth table with the results of sufficiency and the combinations to achieve the desired outcome (HPL). Combination 1 shows R\&D, SHC, PPI, GSR, CS, GCR, and $P C$ that jointly explain an HPL in the wine industry cluster of Baja California. The intermediate and parsimonious solutions are included in the analysis of sufficiency.

Table 7 shows the intermediate solution with only one combination satisfying the 0.80 threshold. A consistency value of 0.99 and a coverage value of 0.81 were achieved in the case of the intermediate solution, while a consistency value of 0.75 and a coverage value of 1 were achieved in the case of the parsimonious solution. Therefore, the intermediate solution shows a single configuration that explains $81.26 \%$ of the cases comprising the desired output with a consistency value of 0.9926 . These results suggest that only one possible path leads to an HPL among firms in the wine industry cluster of Baja California. Even if the interdependent innovations (IINN) condition is not present in the intermediate solution, seven conditions are considered necessary for achieving an HPL in this industry cluster. It is essential to keep in mind that R\&D, SHC, PPI, GSR, CS, GCR, and PC must be jointly present to achieve the desired outcome.

Table 7. Intermediate and parsimonious solutions (consistency threshold: $\mathbf{0 . 8 0}$ )

\begin{tabular}{|c|c|c|c|}
\hline \multicolumn{4}{|l|}{ INTERMEDIATE SOLUTION } \\
\hline Causal Configuration & Row Coverage & Unique Coverage & Consistency \\
\hline$R \& D * S H C * P P I I * G S R * C S * G C R \sim I I N N * P C$ & 0.8126 & 0.8126 & 0.9926 \\
\hline \multicolumn{4}{|c|}{ Solution coverage: 0.812689 ; Solution consistency: 0.99262} \\
\hline \multicolumn{4}{|l|}{ PARSIMONIOUS SOLUTION } \\
\hline Causal Configuration & Row Coverage & Unique Coverage & Consistency \\
\hline IINN & 0.8368 & 0 & 0.7824 \\
\hline R\&D & 0.9365 & o & 0.8266 \\
\hline GSR & 0.9818 & 0 & 0.8333 \\
\hline PC & 0.9758 & 0.0181 & 0.9022 \\
\hline
\end{tabular}

* denotes AND.

$\sim$ denotes absence. 
The parsimonious solution offers four combinations favoring an HPL in the wine industry cluster of Baja California (Table 7). The first configuration demonstrates the absence of IINN with a coverage value of 0.83 and a consistency value of 0.78 , suggesting that firms in this industry cluster do not need to develop IINN to achieve an HPL. The second configuration, R\&D with a coverage of 0.93 and a consistency of 0.82 , implies that firms need to develop R\&D efforts to obtain an HPL. The third configuration, GSR, with a coverage value of 0.98 and a consistency value of 0.83 , suggests the importance of this condition to achieve an HPL. Finally, the fourth configuration, PC, with a coverage of 0.97 and a consistency of 0.90 , demonstrates the importance of this condition to obtaining an HPL.

Table 8 shows the necessary conditions for achieving an HPL in the wine industry cluster of Baja California. The threshold is fixed at 0.80 for evaluating whether a condition is "almost always necessary" (Ragin, 2000). The results show that seven variables are necessary conditions (consistency values above 0.80 ).

Table 8. Necessary conditions (consistency threshold: $\mathbf{0 . 8 0}$ )

\begin{tabular}{l|c|c}
\hline CONDITIONS TESTED & CONSISTENCY & COVERAGE \\
\hline R\&D & 0.936556 & 0.826667 \\
\hline SHC & 0.900302 & 0.735802 \\
\hline PPI & 0.954683 & 0.666667 \\
\hline GSR & 0.981873 & 0.833333 \\
\hline CS & 0.981873 & 0.736961 \\
\hline GCR & 0.936556 & 0.748792 \\
\hline IINN & 0.410876 & 0.552846 \\
\hline PC & 0.975831 & 0.902235 \\
\hline
\end{tabular}

Finally, alternative calibration values were used to test for the validity and robustness of the results. Intermediate solution results show a consistency solution of 0.8126 (above the threshold of 0.80 ) and a coverage solution of 0.9926 . The parsimonious solution shows a consistency solution of 0.7505 and a coverage solution of 1 .

\section{DISCUSSION}

The wine industry cluster of Baja California is moving towards an HPL. An essential feature in this industry cluster is that small and medium-sized firms are responsible for supplying necessary inputs to important wineries. Even if large firms operate with cutting-edge technologies, small and medium-sized wineries have a sizable production capacity. In this sense, Vinos de Liceaga, for example, is a small company that acquired Italian technology, namely, copper and steel alembic for wine production. Another example is Monte Xanic, a medium-size company that invested in novel technology to improve its wine production through innovative irrigation systems. Moreover, this company is a pioneer at using micro-oxygenation and night harvesting to increase the quality of its wines. Vinisterra is another example of a small winery that follows a process in which the wine is well known for its exceptional flavor.

On the other hand, large, medium-sized, and small firms in this wine industry cluster have specialized technical employees who are continuously trained to produce highquality wine. GSR demonstrates how the supply chain in this industry is highly integrated, improving the production capacity of several firms in this cluster. Similarly, government support has been essential to improve the quality of wine production in this industry cluster. The Act for the Promotion of the Wine Industry of 2018, for example, has enabled the development of joint ventures between companies and government agencies in charge of stimulating wine production capacity through the adoption of efficient technologies. However, it is expected that the interaction between wine companies and specialized government agencies, as well as other national and international organizations, will allow the adoption of adequate strategies to promote Mexican wine in national and international markets.

Finally, complementarity between large and medium-sized/ small companies is an essential issue to obtain an HPL in the wine industry cluster of Baja California. A significant percentage of the production capacity of large companies, for instance, depends on agreements established with medium-sized/small producers that could generate synergies and the development of competitive advantage. Mostly, these synergies are drawn from sharing knowledge embodied in specialized human capital.

\section{CONCLUSIONS}

This research shows evidence of sufficiency that leads firms to acquire an HPL in the wine industry cluster of Baja California. The sufficiency configuration was demonstrated by the joint presence of R\&D, SHC, PPI, GSR, CS, and GCR. However, this finding also contributes to supporting the possibility of designing a successful strategy to enable these companies in the wine industry cluster of Baja California to become more competitive. 
Additionally, the evaluation of the parsimonious and intermediate solutions contributes to gaining insight into how the central and peripheral causal conditions contribute to generating an HPL. In this sense, PC, GSR, and R\&D are necessary conditions for achieving an HPL among wineries in the wine industry cluster of Baja California. The absence of IINN in this configuration suggests that firms in the wine industry cluster of Baja California can develop alternative mechanisms to innovate. This finding reinforces the idea that $R \& D$ is a core condition to achieve an $H P L$ in this industry cluster. Finally, results also suggest that R\&D, GSR, and PC are necessary conditions to successfully innovate in the wine industry cluster of Baja California.

\section{REFERENCES}

Alpízar-Padilla, V. A., \& Maldonado-Ávalos, M. M. (2009). Integración de la ruta del vino en Querétaro: Un producto innovador. Quivera, 11(2), 97-109. Retrieved from https://quivera.uaemex.mx/article/ view/10270

Asheim, B., Smith, H. L., \& Oughton, C. (2011). Regional innovation systems: Theory, empirics and policy. Regional Studies, 45(7), 875 891. doi: 10.1080/00343404.2011.596701

Bell, G. G. (2005). Clusters, networks, and firm innovativeness. Strategic Management Journal, 26(3), 287-295. doi: 10.1002/smj.448

Berger, E. S. C. (2016). Is qualitative comparative analysis an emerging method? Structured literature review and bibliometric analysis of QCA applications in business and management research. In E. S. C. Berger, \& A. Kuckertz (Eds.), Complexity in entrepreneurship, innovation and technology research. Switzerland: Springer. doi: 10.1007/978-3-319-27108-8

Bringas, N. L., \& González, J. I. I. (2004). El turismo alternativo: Una opción para el desarrollo local en dos comunidades indígenas de Baja California. Economía, Sociedad y Territorio, 4(15), 551-588. doi: $10.22136 /$ estoo2004421V

Camagni, R., \& Capello, R. (2013). Regional innovation patterns and the EU regional policy reform: Toward smart innovation policies. Growth and Change, 44(2), 355-389. doi: 10.1111/grow.12012

Consejo Mexicano Vitivinícola. (2015). El mercado del vino en México. Retrieved August 15, 2018 from https://www.oemv.es/esp/elmercado-del-vino-en-mexico-2010-277k.php

Consejo Mexicano Vitivinícola. (2018). Le vin et la gastronomie mexicaine. Retrieved August 8, 2018 from http://uvayvino.org.mx/ le-vin-et-la-gastronomie-mexicaine-a-loiv/

Cooke, P. (1992). Regional innovation systems: Competitive regulation in the new Europe. Geoforum, 23(3), 365- 382. doi: 10.1016/00167185(92)90048-9

Cooke, P. (1998). Introduction: Origins of the concept. In H. J. Braczyk, P. Cooke, \& M. Heidenreich (Eds.), Regional innovation systems: The role of governances in a globalized world. London, UK, and New York, USA: Routledge.
Cotte, A., \& Pardo, C.I. (2013). Qualitative comparative analysis (QCA): An application for the industry. Quality \& Quantity, 47, 1315-1321. doi: 10.1007/s11135-011-9592-ov

Covarrubias, J., \& Thach, L. (2015). Wines of Baja México: A qualitative study examining viniculture, enology and marketing prices. Wine Economics and Policy, 4(2), 110-115. doi: 10.1016/j.wep.2015.11.001

Cruz, S., \& Teixeira, C. (2010). The evolution of the cluster literature: Shedding light on the regional studies - regional science debate. Regional Studies, 44(10), 1263-1288. doi: 10.1080/00343400903234670v

Diario Oficial de la Federación. (2018). Ley de fomento a la industria vitivinícola. Retrieved August 15, 2018 from http://www.diputados. gob.mx/LeyesBiblio/ref/lfiv.htm

Edquist, C. (1997). Systems of innovation: Technologies, institutions and organizations. London, UK: Pinter.

El Conocedor. (2016). El mercado del vino mexicano. Retrieved August 6, 2018 from http://revistaelconocedor.com/el-mercado-del-vinomexicano/

El Universal. (2018a). Lo que tienes que saber sobre la legislación del vino mexicano. Retrieved August 7, 2018 from http://www. eluniversal. com.mx/menu/lo-que-tienes-que-saber-sobre-la-legislacion-delvino-mexicano

El Universal. (2018b). Panorama mundial del vino y oportunidades para México. Retrieved August 15, 2018 from http://www.eluniversal.com. $\mathrm{mx} /$ articulo/menu/2017/05/1/mexico-toma-cada-vez-mas-vino

Fiss, P. C. (2007). A set-theoretic approach to organizational configurations. Academy of Management Review, 32(4), 1180-1198. doi: $10.5465 /$ amr.2007.26586092v

Fiss, P. C. (2011). Building better causal theories: A fuzzy set approach to typologies in organization research. Academy of Management Journal, 54(2), 393-420. doi: 10.5465/amj.2011.60263120v

Foray, D., \& Ark, B. Van. (2007). Smart specialization in a truly integrated research area is the key to attracting more R\&D to Europe. Knowledge Economists Policy Brief No. 1. Retrieved from http://ec.europa.eu/ invest-in-research/pdf/download_en/policy_brief1.pdf

Foray, D., Goddard, J., Beldarrain, X. G., Landabaso, M., McCann, P., Morgan, K., ... Ortega-Argilés, R. (2012). Guide to research and innovation strategies for smart specialisation. Luxembourg: Publications Office of the European Union. doi:10.2776/65746

Freeman, C. (1987). Technology policy and economic performance. London, UK: Pinter.

García-Fernández, A., Meraz-Ruiz, L., \& Díaz-Gómez, E. R. (2018). Wine tourism and wine marketing in family-owned micro wineries in Guadalupe Valley, México. Rosa Dos Ventos, 10(4), 690-711. doi: 10.18226/21789061.v10i4p69o

Góngora-Rosado, M. A. (2016). Propuestas de prácticas sustentables en la industria vitivinícola de Baja California México (Master's Thesis, El Colegio de la Frontera Norte).

González-Andrade, S. (2015). The economic value chain of wine in Baja California, Mexico. Estudios Fronterizos, 16(32), 163-193. Retrieved from http://www.scielo.org.mx/pdf/estfro/v16n32/v16n32a6.pdf

Harmaakorpi, V. (2006). Regional development platform method (RDPM) as a tool for regional innovation policy. European Planning Studies, 14(8), 1093-1112. doi: 10.1080/09654310600852399 
Huarng, H. K., \& Roig-Tierno, N. (2016). Qualitative comparative analysis, crisp and fuzzy sets in knowledge and innovation. Journal of Business Research, 69(11), 5181-5186. doi: 10.1016/j.jbusres.2016.04.109

Industrial News Baja Califórnia. (2018). Se impulsa nueva Ley del Vino, la producción e infraestructura nacional. Retrieved August 2, 2018 from https://www.industrialnewsbc.com/2018/06/28/impulsa nueva ley del vino, la producción e infraestructura nacional

International Organization of Vine and Wine. (2010). Definition of vitivinicultural "terroir". International Organization of Vine and Wine Resolutions. Resolution OIV/VITI 333/2010.

Jauhiainen, J. S. (2009). Regional innovation policies in Finland: Towards convergence and/or mismatch? Regional Studies, 42(7), 1031-1045. doi: $10.1080 / 00343400701543140$

Leavy, B. (1996). Outsourcing strategy and a learning dilemma. Production and Inventory Management Journal, 37(4), 50-54.

Leviäkangas, P., Aapaoja, A., Kinnunen, T., Pilli-Sihvola, E., Hautala, R., \& Zulkarnain. (2014). The Finnish road weather business ecosystem: Turning societal benefits into business and the other way round. Engineering Management Research, 3(1), 56-67. doi: 10.5539/emr.v3n1p56

López, M. C., House, L., \& Trejo-Pech, O. C. (2010). Globalization in the wine industry and the case of Baja California, México. 20th Annual World Food and Agribusiness Forum and Symposium, Boston, USA.

Lundvall, B. A. (1992). National systems of innovation: Towards a theory of innovation and interactive learning. London, UK: Pinter.

Malerba, F. (2002). Sectoral systems of innovation and production. Research Policy, 31(2), 247-264. doi: 10.1016/So048-7333(01)00139-1

Martin, R. L., \& Sunley, P. (2003). Deconstructing clusters: Chaotic concept or policy panacea? Journal of Economic Geography, 3(1), 5-35. doi: 10.1093/jeg/3.1.5

Marx, A., Rihoux, B., \& Ragin, C. C. (2014). The origins, development, and application of qualitative comparative analysis: The first 25 years. European Political Science Review, 6(1), 115-142. doi: 10.1017/ S1755773912000318

Maskell, P. (2001). Towards a knowledge-based theory of the geographical cluster. Industrial and Corporate Change, 10(4), 921 943. doi: 10.4324/9781351159203-18

McCann, P., \& Ortega-Argilés, R. (2013). Smart specialization, regional growth and applications to European Union cohesion policy. Regional Studies, 49(8), 1291-1302. doi: 10.1080/00343404.2013.799769

Mendel, J. M., \& Korjani, M. M. (2012). Charles Ragin's fuzzy set qualitative comparative analysis (fSQCA) used for linguistic summarizations. Information Sciences, 202, 1-23. doi: 10.2139/ ssrn.2517981v

Mendel, J. M., \& Korjani, M. M. (2013). Theoretical aspects of fuzzy set qualitative comparative analysis (fSQCA). Information Sciences, 237, 137-161. doi: 10.1016/j.ins.2013.02.048v

Meraz-Ruiz, L. (2015). Estrategias de competitividad de las micro, pequeñas y medianas empresas vinícolas de la Ruta del Vino del Valle de Guadalupe, Mexicali (Master's Tesis, Universidad Autónoma de Baja California).

Meraz-Ruiz, L., \& Ruiz-Vega, A. V. (2016). El enoturismo de Baja California, México: Un análisis de su oferta y comparación con la región vitivinícola de La Rioja, España. Revista Investigaciones Turísticas, 12, 73-98. doi: 10.14198/inturi2016.12.04
Milenio. (2018). Vino mexicano busca llegar a más naciones. Retrieved from http://www.milenio.com/negocios/vino-mexicano-busca-llegara-mas-naciones

Moore, J. F. (1993). Predators and prey: A new ecology of competition. Harvard Business Review, 71(3), 75-86. Retrieved from https://hbr. org/1993/05/predators-and-prey-a-new-ecology-of-competition

Moore, J. F. (2006). Business ecosystems and the view from the firm. The Antitrust Bulletin, 25, 31-75. doi: 10.1177/0003603x0605100103

Nelson, R. R. (1993). National innovation systems: A comparative analysis. Oxford, UK: Oxford University Press.

Padmore, T., \& Gibson, H. (1998). Modelling systems of innovation II: A framework for industrial cluster analysis in regions. Research Policy, 26(6), 625-641. doi: 10.1016/So048-7333(97)00038-3

Parente, T. C., \& Federo, R. (2019). Qualitative comparative analysis: Justifying a neo-configurational approach in management research. RAUSP Management Journal, 54(4), 399-412. doi: 10.1108/RAUSP-052019-0089v

Peppard, J., \& Rylander, A. (2006). From value chain to value network: Insights for mobile operators. European Management Journal, $24(2-$ 3), 128-141. doi: 10.1016/j.emj.2006.03.003

Porter, M. E. (1997). Competitive strategy. Measuring Business Excellence, 1(2), 12-17. doi: 10.1108/ebo25476

Porter, M. E. (1998a). Clusters and the new economics of competition. Harvard Business Review, 76(6), 77-90. Retrieved from https://hbr. org/1998/11/clusters-and-the-new-economics-of-competition

Porter, M. E. (1998b). The Adam Smith address: Location, clusters and the "new" microeconomics of competition. Business Economics, 33(1), 7-13.

Porter, M.E. (2000a). Location, competition and economic development: Local clusters in a global economy. Economic Development Quarterly, 14(1), 15-34. doi: 10.1177/089124240001400105

Porter, M. E. (200ob). Locations, clusters and company strategy. In G. Clark, M. Feldman, \& M. Gertier (Eds.), Oxford handbook of economic geography. Oxford, UK: Oxford University Press.

Porter, M. E. (2008). The five competitive forces that shape strategy. Harvard Business Review, 86, 78-93. Retrieved from https://hbr org/2008/01/the-five-competitive-forces-that-shape-strategy

Porter, M. E., \& Stern, S. (2001). Innovation: Location matters. MIT Sloan Management Review, 42(4), 28-36. Retrieved from https:// sloanreview.mit.edu/article/innovation-location-matters/

Quiñónez-Ramírez, J. J., Bringas-Rábago, N., \& Barrios-Prieto, C. (2011). La ruta del vino de Baja California. Secretaría de Turismo del Estado de Baja California.

Radaelli, C. M., \& Wagemann, C. (2019). What did I leave out? Omitted variables in regression and qualitative comparative analysis. European Political Science, 18, 275-290. doi: 10.1057/s41304-017$0142-7 \mathrm{~V}$

Ragin, C. C. (2000). Fuzzy-set social science. Chicago, USA: University of Chicago Press.

Ragin, C. C. (2006). User's guide to fuzzy-set/qualitative comparative analysis 2.0. Department of Sociology, The University of Arizona, USA.

Ragin, C. C. (2008). Redesigning social inquiry: Fuzzy sets and beyond. Chicago, USA: University of Chicago Press. 
Ragin, C. C., \& Sonnett, J. (2004). Between complexity and parsimony: Limited diversity, counterfactual cases, and comparative analysis. In S. Kropp, \& M. Minkenberg (Eds.), Vergleichen in der Politikwissenschaft VS Verlag für Sozialwissenschaften. doi: 10.1007/978-3-322-804419_9v

Rihoux, B., \& Ragin, C. C. (2009). Configurational comparative methods. Thousand Oaks, USA/New Delhi, India/London, UK/Singapore: Sage.

Rinkinen, S., \& Harmaakorpi, V. (2018). The business ecosystem concept in innovation policy context: Building a conceptual framework. Innovation: The European Journal of Social Science Research, 31(3), 333-349. doi: 10.1080/13511610.2017.1300089v

Rodríguez, J. C., Gómez, M., \& Ramírez, K. N. (2015). Competitive advantage in knowledge-based firms of emerging economies: Evidence from Mexico. International Journal of Globalisation and Small Business, 7(1), 39-58. doi: 10.1504/ijgsb.2015.069035

Roelandt, T. J. A., \& Hertog, P. den. (1999). Cluster analysis and clusterbased policy making: The state of the art. Boosting innovation: The cluster approach. OECD Proceedings. Paris, France: OECD.

Roig-Tierno, N., González-Cruz, T. F., \& Llopis-Martínez, J. (2017). An overview of qualitative comparative analysis: A bibliometric analysis. Journal of Innovation \& Knowledge, 2(1), 15-23. doi: 10.1016/j. jik.2016.12.002

Roig-Tierno, N., Huarng, K. H., \& Ribeiro-Soriano, D. (2016). Qualitative comparative analysis: Crisp and fuzzy sets in business and management. Journal of Business Research, 69(4), 1261-1264. doi: 10.1016/j.jbusres.2015.10.089v
Schneider, C. Q., \& Wagemann, C. (2010). Qualitative comparative analysis (QCA) and fuzzy-sets: Agenda for a research approach and a data analysis technique. Comparative Sociology, 9(3), 376-396. doi: $10.1163 / 156913210 \times 12493538729838 \mathrm{v}$

Schneider, C. Q., \& Wagemann, C. (2012). Set-Theoretic methods for the social sciences: A guide to qualitative comparative analysis. Cambridge, UK: Cambridge University Press.

Secretaria de Fomento Agropecuario. (2011). Estudio estadístico sobre producción de uva en Baja California. Gobierno del Estado de Baja California/Secretaría de Agricultura, Ganadería, Desarrollo Rural, Pesca y Alimentación. Retrieved from http://www. nacionmulticultural.unam.mx/empresasindigenas/docs/1873.pdf

Smits, R., \& Kuhlmann, S. (2004). The rise of systemic instruments in innovation policy. International Journal of Foresight and Innovation Policy, 1(1-2), 4-32. doi: 10.1504/ijfip.2004.004621

Trejo-Pech, C. O., Arellano-Sada, R., Coelho, A. M., \& Weldon, R. N. (2012). Is the Baja Califórnia, Mexico, wine industry a cluster? American Journal of Agricultural Economics, 94(2), 569-575. doi: 10.1093/ajae/aaro80

Vis, B. (2012). The comparative advantages of fsQCA and regression analysis for moderately large-n analyses. Sociological Methods \& Research, 41(1), 168-198. doi: 10.1177/0049124112442142

Wines of Baja. (2013). Wines of Baja: Renewing the history of Mexico's wines. Retrieved August 8, 2018 from http://www.chiff.com/a/winebaja.htm

\section{AUTHOR'S CONTRIBUTIONS}

José Carlos Rodríguez, Mario Gómez and María Aline Manzo equally contributed to the conceptualization and theoreticalmethodological construction, theoretical review, data collection, data analysis, and writing and final review of this paper. 